\title{
Historical Shifts in Benthic Infaunal Diversity in the Northern Gulf of Mexico since the Appearance of Seasonally Severe Hypoxia
}

\author{
Nancy N. Rabalais ${ }^{1, *}$ and Melissa M. Baustian ${ }^{2}$ D \\ 1 Louisiana State University, Baton Rouge, LA 70803, USA \\ 2 The Water Institute of the Gulf, Baton Rouge, LA 70802, USA; mbaustian@thewaterinstitute.org \\ * Correspondence: nrabal@lsu.edu; Tel.: +1-985-870-4203
}

Received: 10 December 2019; Accepted: 24 January 2020; Published: 28 January 2020

check for updates

\begin{abstract}
Severe and persistent bottom-water hypoxia ( $\leq 2 \mathrm{mg} \mathrm{O}_{2} \mathrm{~L}^{-1}$ ) occurs on the Louisiana/Texas continental shelf from mid-May through mid-September over a large area (up to $23,000 \mathrm{~km}^{2}$ in mid-summer). Benthic infauna are less mobile than demersal organisms and become stressed by the low dissolved oxygen; benthic community composition, abundance, diversity, and biomass become altered. From the 1950s to the early 1970s, when sediment core indicators identified the initiation and subsequent worsening of dissolved oxygen conditions, there were no hydrographic data or benthic infaunal studies within the current area of frequent bottom-water hypoxia. This study highlights the impacts of severe hypoxia on benthic macroinfaunal communities and how they may have changed from less-hypoxic periods. Polychaetes were and are the dominant taxa in the available studies, but polychaete species richness in summer is now curtailed severely beginning with our 1985-1986 data. Species richness of polychaetes in summer hypoxia (1985-1986 and 1990-1991) was about 60\% less than comparable taxa in 1972-1973. Abundance of polychaetes was much less in summer than spring, and recent infaunal biomass in summer was only $15 \%$ of what was found in spring. The result is less prey for demersal penaeid shrimp and fishes. Over the period of our comparison, infaunal feeding modes shifted from subsurface deposit feeders and surface deposit feeders to primarily surface deposit feeders (i.e., 95.5\% of all polychaetes). Most were opportunistic, hypoxia tolerant, and recruited in high numbers following hypoxia abatement, some in fall and winter but most in spring. As benthic communities succumb to the stress of severe and continued seasonal low oxygen, they occupy the few upper centimeters of the sediment profile above the redox discontinuity layer with negative feedbacks to the water column by way of altered biogeochemical processes.
\end{abstract}

Keywords: benthos; oxygen deficiency; hypoxia; Polychaeta; environmental stress; community recovery; historical ecology

\section{Introduction}

The northern Gulf of Mexico west of the Mississippi River delta and its efflux of fresh water, sediments, and nutrients is known for its large area of low oxygen (i.e., hypoxia) in the bottom waters, occurring annually from spring to fall [1]. The area of bottom waters with less than $2 \mathrm{mg} \mathrm{O}_{2} \mathrm{~L}^{-1}$, i.e., our accepted definition of hypoxia [2], averaged $14,042 \mathrm{~km}^{2}$ over the last 30 years and maintained a 5 -year running average of $15,520 \mathrm{~km}^{2}$ as of 2019 , compared to an environmental goal of $5000 \mathrm{~km}^{2}$ [1]. Anoxia $\left(0.0 \mathrm{mg} \cdot \mathrm{L}^{-1}\right.$ of dissolved oxygen) also occurs with the generation of toxic hydrogen sulfide. The year to reach this size goal was extended from 2015 (established in 2001 [3]) to 2035 with intermediate goals of nutrient load reductions in watershed subunits [4].

Quantifiable reductions related to the bottom-water hypoxic area and the nutrient reduction load goals have been logistically and socially difficult to achieve and perpetuate the poor ecosystem health 
of a large area of the northern Gulf of Mexico and numerous conditions of poor water quality within the Mississippi River watershed [1]. The hypoxic bottom-waters of the northern Gulf of Mexico support less suitable habitat for demersal commercial and recreational fisheries compared to normoxic (or less hypoxic) conditions [5-7], diminish the occupation by commercial and recreational fishers [8-10], and disrupt the natural processes that support healthy coastal ecosystems [11].

Components of the food web that support the valuable demersal fisheries of the northern Gulf of Mexico in the shadow of the Mississippi River plume rely on the nutrient-enriched waters of the Mississippi River. Currently, and especially since the 1970s to 1980s, the productivity of the Mississippi River-influenced nutrient-enriched waters has led to bottom-water habitat degradation in its shadow, including the formation of bottom-water low dissolved oxygen concentrations across broad expanses of the northern Gulf of Mexico continental shelf west of the Mississippi River delta (Figure 1) [12].

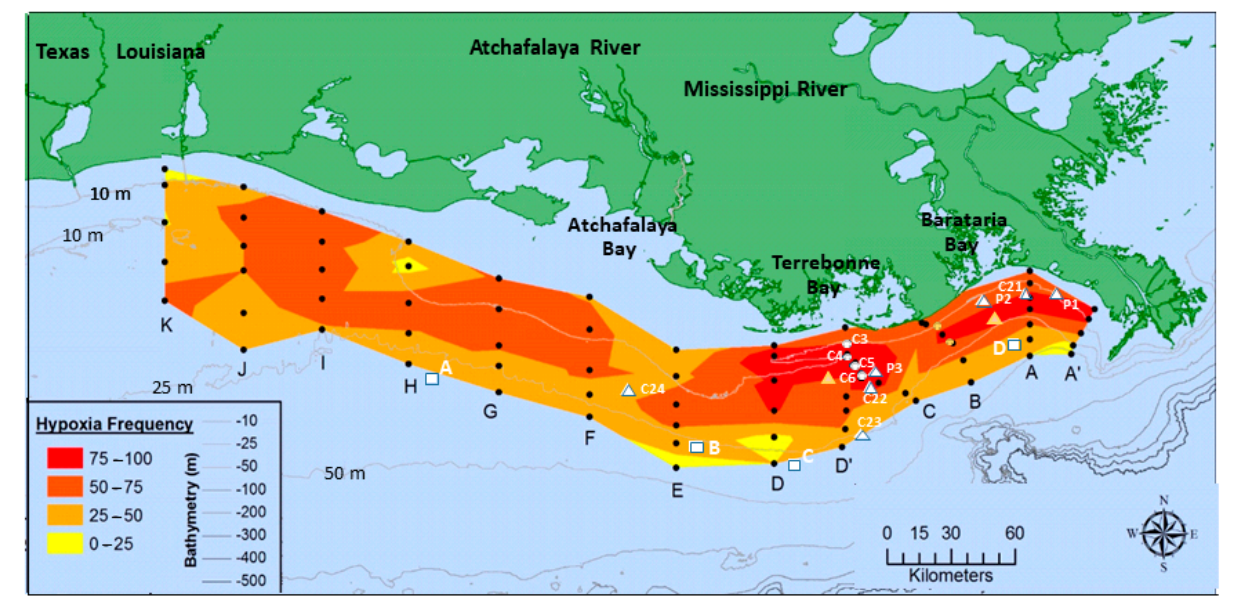

Figure 1. The frequency of bottom-water hypoxia occurrence from mid-summer shelfwide hypoxia mapping from 1985 through 2014 (modified from [13]). Frequency is determined from stations for which there are data for at least half of all cruises (identified by black dots and letters). Macroinfauna data from studies used in the community comparisons are indicated by white circles [14,15], yellow circles for a long-term dissolved oxygen time series [16], orange triangles [15], open triangles [17], squares [18], and studies [19] near station C6 of Rabalais et al. [15].

A phytoplankton-enhanced upper water column contributes to the flux of organic carbon to the lower water column and seabed. The water column is stratified seasonally by both temperature and freshwater inflow. Respiration of carbon in the bottom layer exceeds the resupply of oxygen from the surface waters across the pycnocline, and bacterial respiration drives bottom-water dissolved oxygen to levels insufficient to support most marine life [2]. Hydrographic data that identify areas of bottom-water oxygen deficiency for this area date only to the early 1970s [20] but dated sediment cores identify numerous indicators of ecosystem change from much earlier. Indicators of ecosystem change include increased accumulation of carbon and diatom remnants, shifts in C, N, and S isotopic signatures, increase in glauconite minerals (related to worsening redox conditions in surface sediments), loss of biodiversity of ostracods and foraminiferans, and species shifts within diatoms and foraminiferans [12,21]. Shifts in biological and chemical indicators of increased productivity in overlying waters and worsening oxygen deficiency in the bottom waters paralleled increased nitrogen loads from the Mississippi River to the continental shelf west of the Mississippi River delta beginning approximately in the 1950s, accelerating in the 1960s to 1970s, and becoming most pronounced in the 1990s [12,21].

The earliest studies that documented oxygen deficiency on the Louisiana continental shelf west of the Mississippi River were in 1972-1974 [22-24] (detailed in [20]). Systematic surveys to document the suspected widespread occurrence of hypoxia $[25,26]$ resulted in reports of hypoxia offshore of Terrebonne Bay in March 1975, over a fairly large area offshore of Barataria and Terrebonne bays in July 1975, at one station off Terrebonne Bay in July 1976, and in the Louisiana bight and west of the 
Atchafalaya River delta in September 1975, July 1975, and August 1976. Further studies in support of groundfish surveys and environmental assessments of oil and gas production activities from 1978 to 1984 documented low bottom-water oxygen levels in areas where hypoxia is currently present [15].

A systematic documentation of broad-scale oxygen deficiency on the Louisiana continental shelf began in 1985 with mid-summer surveys from the Mississippi River delta to the Louisiana/Texas state border or further west as needed $[1,27]$ at least until present (2019). The first surveys of benthic macroinfauna in the current area of frequently occurring hypoxia (Table 1) west of the Mississippi River delta began in 1972-1973 in connection with oil and gas production [19], followed in 1978 by [17], and a series of samples in 1978-1995 with the Louisiana Offshore Oil Port (LOOP) study [16], again associated with the petroleum industry. Benthic studies began in 1985-1986 in areas of current and seasonally persistent low oxygen conditions on the Louisiana continental shelf to better understand the impacts of hypoxia on coastal ecosystems [14,28] (Figure 1) and continued in 1990-1991 [15] and 2003-2004 [29,30].

Table 1. Selected studies of benthic macroinfauna in the Louisiana bight and adjacent areas where summer bottom-water hypoxia is frequently present (Figure 1).

\begin{tabular}{ccccc}
\hline $\begin{array}{c}\text { Year of Benthic } \\
\text { Infauna Data }\end{array}$ & $\begin{array}{c}\text { Stations in } \\
\text { Figure } 1\end{array}$ & Depth $\mathbf{( m )}$ & Months of Study & Study Citation \\
\hline $1972-1973$ & Near C6 & $18-21$ & Spring, Summer & {$[19]$} \\
1978 & White triangle & $14-21,29-37$ & May, August & {$[17]$} \\
$1978-1996$ & Yellow circle & $9-25$ & Seasonal & {$[16,31,32]$} \\
$1985-1986$ & C3-C5, white circle & $10,13,16$ & Monthly & {$[14]$} \\
$1990-1991$ & Yellow triangle & $20-21$ & Monthly & {$[15]$} \\
2004 & C6, white circle & 21 & Monthly & {$[30]$} \\
\hline
\end{tabular}

To declare when consistently low dissolved oxygen conditions in spring through late summer were documented on the Louisiana continental shelf is difficult because of the lack of monthly or seasonal hydrographic data for the area since 1950. Three data sets can contribute to such a determination: (1) the sediment core information (addressed above), (2) the environmental assessment data from the Louisiana Offshore Oil Port (LOOP) facilities (Figure 2) [16,24], and the series of studies beginning in $1985[1,27]$ of mid-summer shelfwide and monthly or bimonthly studies of hypoxia on the Louisiana continental shelf. The LOOP study included stations of a brine diffuser station near $9 \mathrm{~m}$ water depth and the main offloading facility in 30 to $35 \mathrm{~m}$ water depth as well as a series of stations parallel to the pipeline in depths of 15.2 to $26.5 \mathrm{~m}$ ) [31,32]. Hydrographic data documented a gradual transition from no low bottom-water oxygen conditions in 1978 to the more frequent low dissolved oxygen levels beginning in the mid-1980s and the early 1990s (Figure 2). An earlier environmental assessment as background to the broader LOOP sampling protocol indicated two months of the year in 1973 and 1974 where oxygen deficiency was present [24]. Hypoxia occurred in 0 to 3 months of the year in 1978-1983 and increased in 1984 for 3 to 8 months of the year until 1995 when the program ended. Of the years from 1984 to 1995, hypoxia occurred in 83\% of the months of June, July, and August [24]. The decrease in the bottom-water dissolved oxygen levels paralleled the increase in surface water productivity in the same area as influenced by the increased nutrient loads of the Mississippi River to the continental shelf west of the river delta [12,21].

We detailed the potential historical timing of increasing hypoxia on the Louisiana continental shelf west of the Mississippi River in the Louisiana bight to provide a context for our predictions of how benthic infaunal communities may have changed from a plausible historic context into the benthic communities of the continental shelf in the period 1950-2020. We suggest that the benthic community prior to persistent low oxygen conditions was a deeper-burrowing, more diverse benthic infauna that transitioned to a community of surface deposit feeders that were less diverse, more opportunistic, and found in high abundance in the upper few centimeters of the sediment surface (Figure 3). These shifts would necessarily change the biogeochemistry of the sediments to bring the redox discontinuity layer closer to the surface in the sediment profile and shift biogeochemical processes (Figure 3). 
Our prediction is in the context of the original model of Pearson and Rosenberg [33] that is related to the recovery of benthic infauna in a distance gradient from pollution (paper mill pulp). Others [18] also used the Pearson and Rosenberg model with respect to Louisiana continental shelf macroinfauna in a geographical distance from severe hypoxia stress to no oxygen stress. We propose the model below as a temporal shift over multiple years from a historic healthy macroinfaunal community to the recent hypoxia-stressed benthic community on the Louisiana continental shelf.

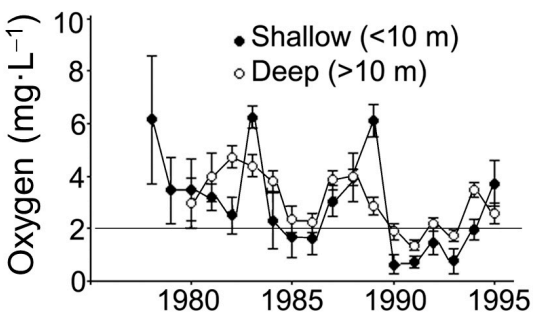

Figure 2. Bottom-water oxygen concentration $\left(\mathrm{mg} \cdot \mathrm{L}^{-1}\right)$ for shallow and deep water stations for combined observations from June, July, and August (mean \pm 1 S.E.) 1978-1995. Source [16], derived from data in [24].

Whether the benthic infaunal community was consistent with a circa 1950s benthic community or could return to that condition, a presumed healthier ecosystem, as represented by our proposed model in Figure 3 is unknown. In the interim of the 1950s to present, the oil and gas industry has expanded in inshore and offshore waters, a major oil spill occurred in 2010 [13], and climate has changed with resultant increased bottom-water temperatures in the area [34]. Seabed trawling activity for commercially-viable penaeid shrimps is a frequent [35] potential disturbance in the study area, but no evidence demonstrates impacts on the fine-grained sediments of the study area [36,37]. Hurricanes, frequent in the northern Gulf of Mexico, are also potential sediment resuspension and redistribution mechanisms [38]. Given these multiple stressors, is a return to pre-frequent bottom-water hypoxia benthic communities possible [39]?

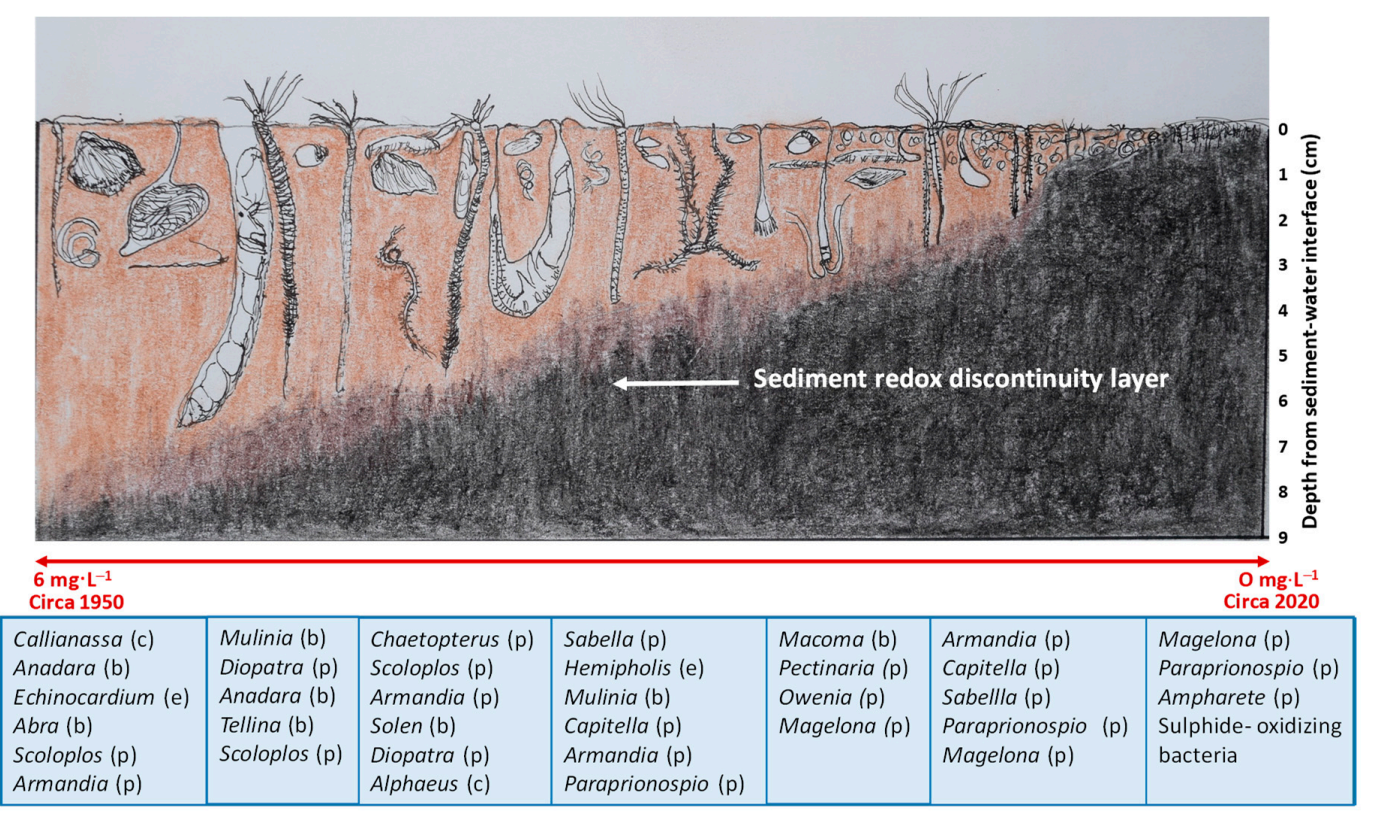

Figure 3. Changes in benthic infauna (by genera) and sediment structure including the redox discontinuity layer from well-oxygenated waters on the left, likely representing years circa 1950, to no oxygen on the right, representing years circa 2020 (modified from [11,33]). (Letters are (b) bivalve, (c) crustacean, (e) echinoderm, (p) polychaete). 


\section{Materials and Methods}

Our ability to identify benthic community changes over a period of transition from limited, minimal, or no oxygen deficiency to the current situation of persistently severe seasonal bottom-water oxygen deficiency would ideally require complete sets of benthic macroinfauna data from the 1930s to the 1950s to present in similar habitats. However, data on benthic macroinfauna communities were limited prior to 1985 . We found a variety of studies, which used different sampling techniques (sometimes not identified), focused on different groups of organisms, calculated different benthic community indices, were in different depths or sedimentary regimes, and were often temporally restricted. Most data were in grey literature, i.e., agency reports, industry reports, or dissertations. The few journal articles were from areas that experienced oxygen deficiency but were not spatially comparable to the 1985-present area of high frequency summer hypoxia. Earlier work, for example on the upper Texas coast and the western Louisiana shelf, while out of our targeted study area, provided insight on different faunal communities affected by seasonal hypoxia in the years 1979 and 1981-1982 [40-42].

We sought benthic macroinfauna data from the geographic area where summer hypoxia occurs frequently (Figure 1) that could be paired with data from periods of spring recruitment and summer oxygen deficiency, where sediments were primarily sandy mud and where depths were in a range of 15-25 m (Table 1, Appendix A.1, Appendix A.2, Appendix B). We used a thesis by Fitzhugh [17] that focused only on polychaetes in 1978, and we compared those results to the raw data [14] of the 1985-1986 studies mentioned in [28]. An additional study [19,43] from the Offshore Ecology Investigation [22] examined sediments near offshore oil and gas production platforms and control sites from 1978 and focused primarily on molluscs and crustaceans, with little information on polychaetes. The 1978 data on polychaetes [17], however, were useful in comparing the selected taxa to more recent studies. We used data from years 1985-1986 [14,28], 1990-1991 [15], and 2004 [30] to define more recent seasonally low oxygen conditions and the associated benthic macroinfauna conditions. Seasonal studies in 2009-2010 [18], while intended to focus on hypoxia stress, did not meet the criteria for our depth distribution (i.e., being too deep) (Figure 1) and were therefore limited in hypoxia exposure. Their work, however, did provide a comprehensive summary of feeding guilds for Louisiana continental shelf macroinfauna [44]. For all data sets, we focused only on generic names to avoid taxonomic species changes over time; most genera included just one species. The overall data were too disparate for statistical analyses.

Specific methods of the studies will be provided in the relevant comparisons because they were conducted with different methodologies, focused on different taxa, or calculated different units or indices for benthic community parameters. Because of all these disparities, statistics were not applicable to the comparisons.

\section{Results}

\subsection{Central Gulf Platform Study in 1978}

Fitzhugh [17] provided the most comparable data to recent benthic studies. The study was restricted to polychaetes from the larger study of "Ecological Investigations of Petroleum Production Platforms in the Central Gulf of Mexico" [43]. The stations are identified by white triangles in Figure 1; general parameters are in Appendix A.1. Spring samples were collected in May 1978 (high Mississippi River discharge, $35 \times 10^{3} \mathrm{~m}^{3} \cdot \mathrm{s}^{-1}$ ) and in August 1978 (low Mississippi River Discharge $\left(14 \times 10^{3} \mathrm{~m}^{3} \cdot \mathrm{s}^{-1}\right)$ [17]. The samples were collected with a Smith-cIntyre grab $\left(0.1 \mathrm{~m}^{2}\right)$ and converted to parameters per $\mathrm{m}^{2}$ for histograms in [17] but not in the appendices (Appendix A.2); the size range was $\geq 0.5 \mathrm{~mm}$.

The spring and summer data for 1978 (number of individuals per station, Appendix A.2) [17] indicated a drop in abundance of polychaetes between spring and summer from an average abundance of 1957 individuals per station in spring to 71 individuals per station in summer when hypoxia was 
present (Figure 4). There was also a marked drop in polychaete species richness for the same period from about 36 polychaete species per station in spring 1978 to 13 polychaete species per station in summer 1978. These values represent an approximate 100-fold and a 3-fold decline for individuals and species, respectively. The $75 \%$ most abundant species occurring in summer in [17] were still observed in the 1985-1986 study (see below). Genera that occurred in the spring, but not in the summer, were Sigambra, Notomastus, Lumbrineris, Diopatra, Cossura, Nereis, and Nephthys (Appendix C).

\subsection{Benthos Studies in 1985-1986}

Data from stations C3, C4, and C5 off Terrebonne Bay [14] in 1985-1986 (seven years after the 1978 studies [17]) were compiled for comparison to the data in 1978. The benthic infauna [14] were collected with a modified Zajak sampler with 6.6-cm I.D. core tubes. The organisms from four, five, or six cores $\left(\geq 0.5 \mathrm{~mm}\right.$ ) were consolidated into values for conversion to number of polychaetes $\mathrm{m}^{-2}$. We focused only on the polychaetes and comparable parameters in spring (high spring recruitment) versus summer (low dissolved oxygen and stressed benthic communities) similar to [17]. The polychaete data for 1985-1986 are in Appendix B.

There were depth-related transitions in the abundance of polychaetes and number of polychaete species for stations $\mathrm{C} 3, \mathrm{C} 4$, and C5, in 10, 13, and $16 \mathrm{~m}$, respectively (Table 1, Appendix B). The polychaete community data for stations C4 and C5 [14] were most comparable to the 1978 hypoxic stations of 14-21 m [17] but not to the non-hypoxic stations C23 and P3 of 37 and $29 \mathrm{~m}$, respectively. The data for [14] are plotted in Figure 5, but data for station C3 are excluded, which was in a different depth and sedimentology compared to others [14].

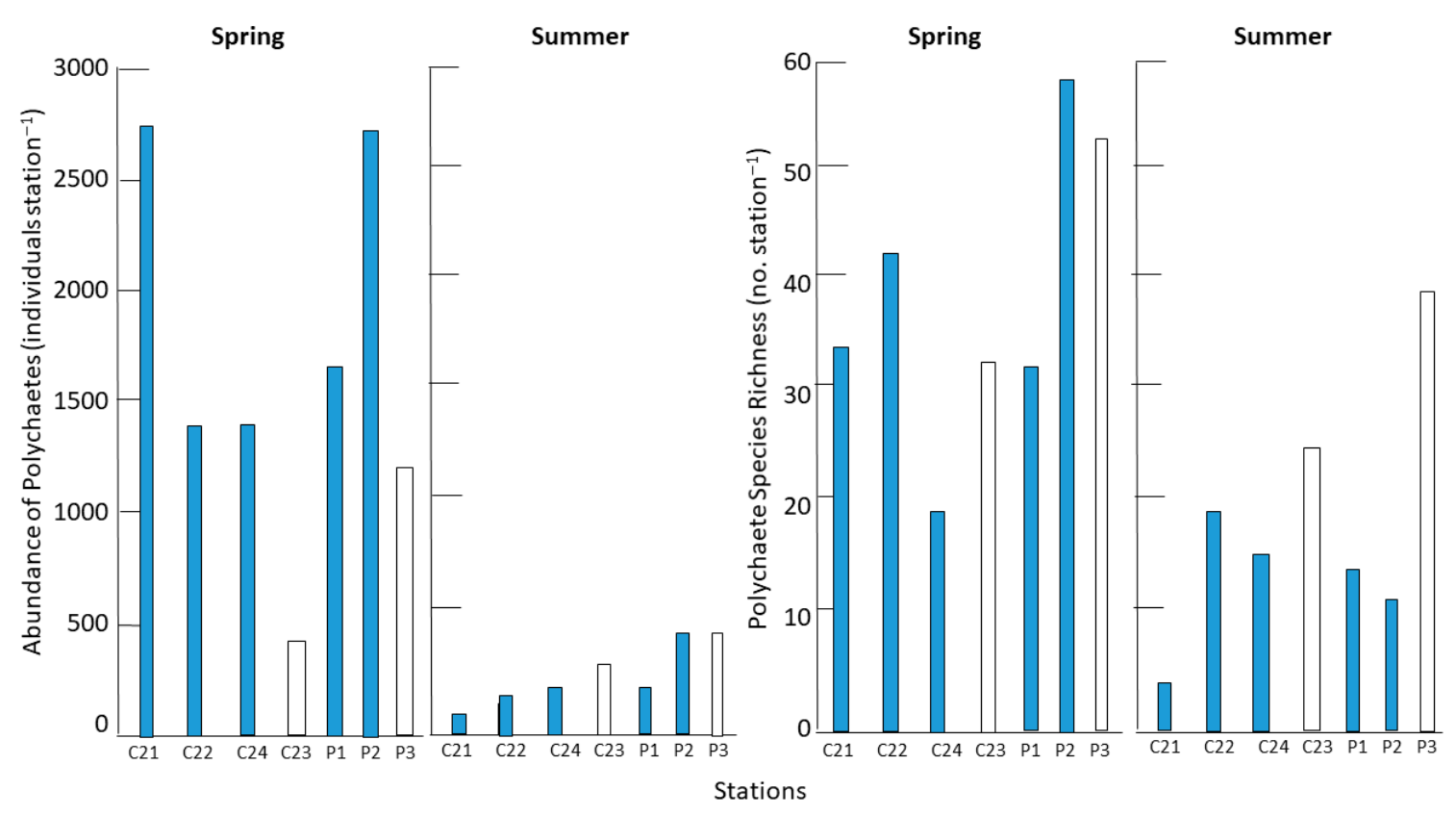

Figure 4. Comparison of benthic infauna data for abundance of polychaetes per station and number of polychaete species per station in May and August of 1978 [17]. Two stations P3 and C23 (29 and $37 \mathrm{~m}$, respectively) were not hypoxic (white histograms) compared to the other stations of 14 to $21 \mathrm{~m}$ that were hypoxic (blue histograms) (Appendix A.1 and A.2). 


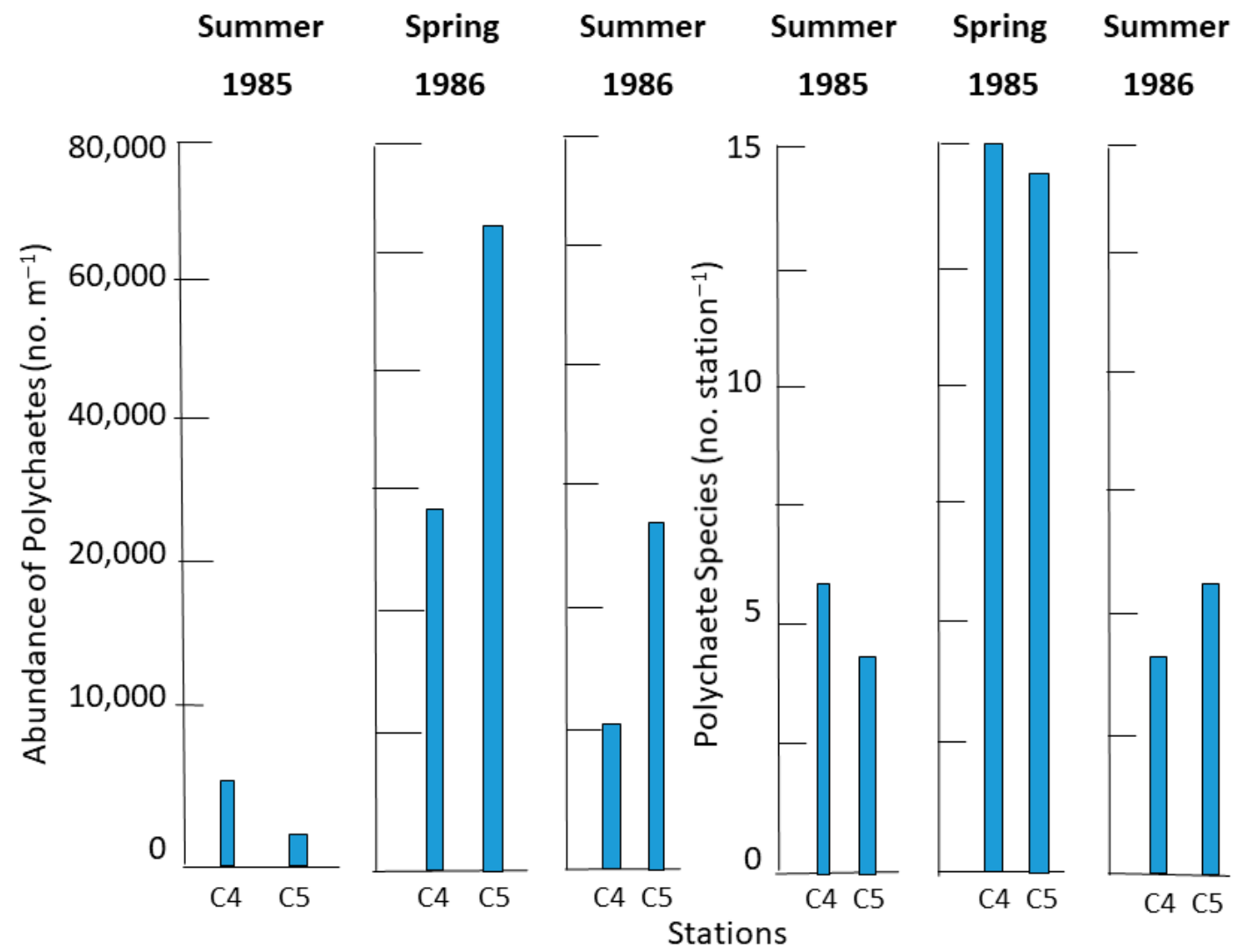

Figure 5. Data from macroinfauna studies in 1985 and 1986 on the Louisiana continental shelf from stations C4 and C5 [14] (Appendix B) for comparison to the 1978 data [17]. Data in this figure were restricted to polychaete abundance and species. The blue color identifies hypoxic conditions.

Data from stations C4 and C5 off Terrebonne Bay [14] in 1985-1986 (six years post studies in 1978 [17]) were the most comparable for polychaete species richness to data in 1978 [17]. The disparate polychaete abundance data in 1978, by $\mathrm{m}^{2}$ or by station [17], precluded a direct comparison to the polychaete abundance per $\mathrm{m}^{2}$ in 1985-1986 [14] and could only be compared between spring and summer of the same time period. Both the 1978 [17] study and the 1985-1986 study [14] identify a period of high spring recruitment related to high surface phytoplankton production and flux of carbon to the bottom layer and a decrease in abundance and species of polychaetes in the following summer during severe low oxygen conditions (Figures 4 and 5). Spring abundance in 1985-1986 [14] was higher than in summer, and the number of species in spring 1985-1986 was also higher than in summer for the same years. The number of polychaete species per station in 1978 [17] of 9.8 was reduced two-fold in 1985-1986 to 4.6 polychaete species per station [14]. Common polychaetes in summer 1985-1986 with bottom-water hypoxia were Paraprionospio, Magelona, Ancistrosyllis, Ampharete, and Sigambra, but were only a subset of a greater number of taxa in summer 1978 [17] (Appendix C). Other fauna in 1985-1986 included a few sipunculans, phoronids, enterpneusts, actinarians, hemichordates, gastropods, and bivalves. Polychaetes comprised an average of $97 \%$ of all macroinfauna in 1985-1986. The polychaete composition average was higher in summer than spring, fall, or winter, suggesting that other taxa were eliminated.

\subsection{Offshore Ecology Investigation in 1972-1973}

Benthic macroinfaunal communities in spring and summer 1972-1973 were collected with a $0.2-\mathrm{m}^{2}$ Van Veen grab [19] sieved at $\geq 0.5 \mathrm{~mm}$, from within the broader studies of the Offshore Ecology Investigation [22] located in Terrebonne Bay and nearby offshore waters in $\sim 20 \mathrm{~m}$. The offshore stations were similar in depth and sedimentology to the studies already summarized for 1978 [17] 
and 1985-1986 [14]. Unlike Fitzhugh's focus on polychaetes [17], Farrell [19] focused on molluscs and crustaceans and reported relative proportions in biomass units. These data were not comparable to abundance or species richness values for 1978 or 1985-1986 data. A ranked list of taxa in 1972-1973, however, could be compared to the non-polychaete taxa in 1985-1986 [14]. The latter were less diverse compared to similar taxa in spring and summer of 1972-1973 [19]. The benthic community in 1985-1986 [14] had fewer molluscs, decapod crustaceans, and pericaridean crustaceans, e.g., amphipods and isopods, than in 1972-1973 [19]. Many pericarideans' reproductive strategy is egg brooding and direct development rather than recruitment from the plankton and they are more susceptible to hypoxic events. The recovery of amphipods in a study of hypoxia effects on benthic infauna on the upper Texas coast [37] indicated that amphipods were annihilated during severe summer hypoxia and continued to be extremely low in the following spring and summer. The 1985-1986 results [14] were consistent with the work on the upper Texas coast [40], in similar water depths but different sedimentology, with regard to the lack of pericaridean crustaceans during 1979-1980.

The Offshore Ecology Investigation study [19] mentioned that the July 1973 bottom dissolved oxygen values reached a mean low of $1.4 \mathrm{mg} \cdot \mathrm{L}^{-1}$ in a broad area of stations associated with the primary and control stations for that project and that fish kills were observed during that period. Their analysis of biomass data for benthic macroinfauna indicated that the July 1973 benthic biomass values were significantly lower than the prior sampling period in spring 1973. The Mississippi River discharge for spring 1973 was a record high flow for the river since the early 1800s [42], and benthic macroinfauna community characteristics reflected the extremely low oxygen conditions that followed in July 1973. A value of $1.4 \mathrm{mg} \cdot \mathrm{L}^{-1}$ in 1973, however, does not approach the values of less than $1 \mathrm{mg} \cdot \mathrm{L}^{-1}$ or near anoxia that may now last from 0.5 to 2 months from May to September in this area [27].

\subsection{Louisiana Offshore Oil Port (LOOP) in 1980-1995}

These benthic data are offshore samples consistent with the LOOP dissolved oxygen data and were taken with a Smith-McIntyre grab $\left(0.1 \mathrm{~m}^{2}\right)$ and sieved at $\geq 0.5 \mathrm{~mm}$. The benthic data are not readily available for seasonal comparisons within this study area and reports often combined all seasons into an annual average [32]. When available, the data were averaged across year or by depth gradient, which was not often clear. Diversity data were expressed as indices and did not provide suitable data for comparison with other studies, which enumerated all taxa, or all taxa within a larger unit, such as "phyla." Appropriate data were identified, and we focused on the 20- to 30-m station as the most comparable to more recent work.

In 1980, for example, total taxa in spring versus summer were 58.5 versus 45.0 per station, and for the same period, abundance was 3600 versus $2500 \mathrm{~m}^{-2}$, with a spring bottom-water dissolved oxygen of 4.8 versus $1.6 \mathrm{mg} \cdot \mathrm{L}^{-1}$ in summer The same parameters in 1992 were spring and summer total taxa of 50.2 and 23.2 taxa per station, abundance of 1646 versus $269 \mathrm{~m}^{-2}$, with a boundary of 5.37 versus $0.50 \mathrm{mg} \cdot \mathrm{L}^{-1}$ for dissolved oxygen. These values demonstrated the spring recruitment period versus summer hypoxia and decreasing species richness and abundance with decreasing dissolved oxygen concentrations. These data were not comparable to other studies because the other studies dealt with taxonomic groups rather than all taxa.

\subsection{Benthic Assemblages in 1990-1991}

The benthic community dynamics for the Louisiana continental shelf where low oxygen conditions are seasonally severe are well illustrated by [15] for 1990-1991. During the 1990-1991 period, near-bottom deployed oxygen meters captured 15-min intervals of dissolved oxygen conditions at two stations (orange triangles in Figure 1). One of the study areas was on the edge of tidally-advected hypoxia, and the low oxygen values were intermittent [45]. The other study area near C6 (Figure 1) was in an area of persistently severe bottom-water low oxygen, and often anoxia, for much of the summer (Figure 6) [45]. 


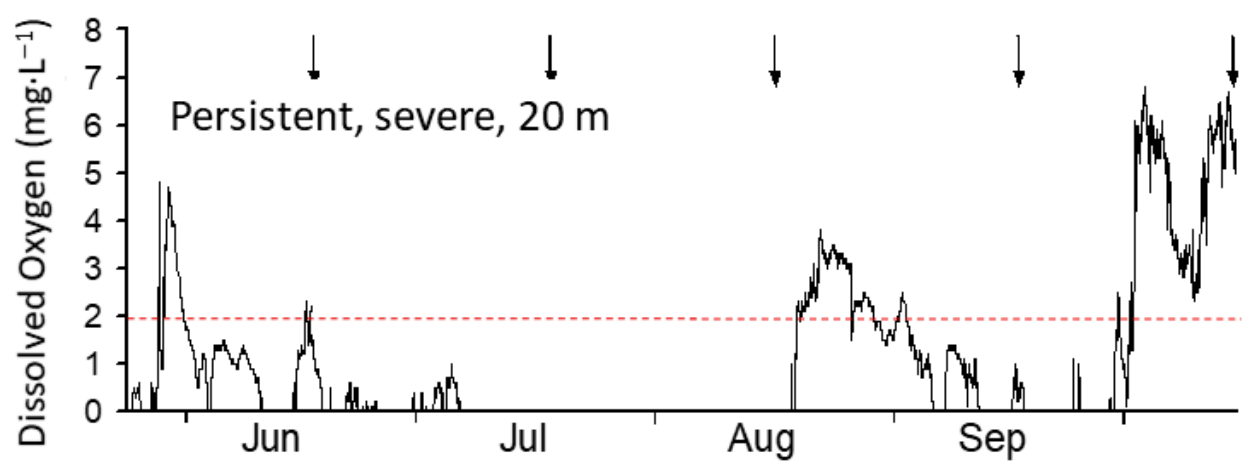

Figure 6. Time series plot of near-bottom dissolved oxygen concentration at a 21-m station (C6) that is $100 \mathrm{~km}$ west of the Mississippi River delta in 1990 [15,45]. The horizontal dashed line defines hypoxia. Zero values indicate anoxia or close to anoxia $0.0 \pm 0.2 \mathrm{mg} \cdot \mathrm{L}^{-1}$. Arrows indicate sampling periods from June 1990 through October 1990 that correspond with benthic communities in Figure 7.

Benthic samples were taken from a 0.1- $\mathrm{m}^{2}$ GOMEX box corer into which a small, hand-operated Ekman grab $\left(0.023-\mathrm{m}^{2}\right.$ surface area) was inserted for a series of five replicate samples. Organisms captured on a $\geq 0.5-\mathrm{mm}$ sieve were analyzed.

Polychaete species, as with all studies described previously, were the dominant taxa at the C6 station when the dissolved oxygen levels were the lowest in summer (Figure 7). The abundance and diversity were much lower in summer than in spring at this station. The same five species that maintained nominal abundances at the lowest dissolved oxygen concentrations as in the 1985-1986 samples [14] were dominant in spring and maintained minimal abundances at the lowest dissolved oxygen concentrations as in the summer 1990 samples. These were mostly small, opportunistic, and hypoxia-tolerant surface deposit feeders-the polychaetes Paraprionospio pinnata, Magelona sp. and Ampharete sp., and the sipunculid Asphidosiphon sp. (see Discussion)—and the opportunistic, subsurface deposit feeder Mediomastus sp.

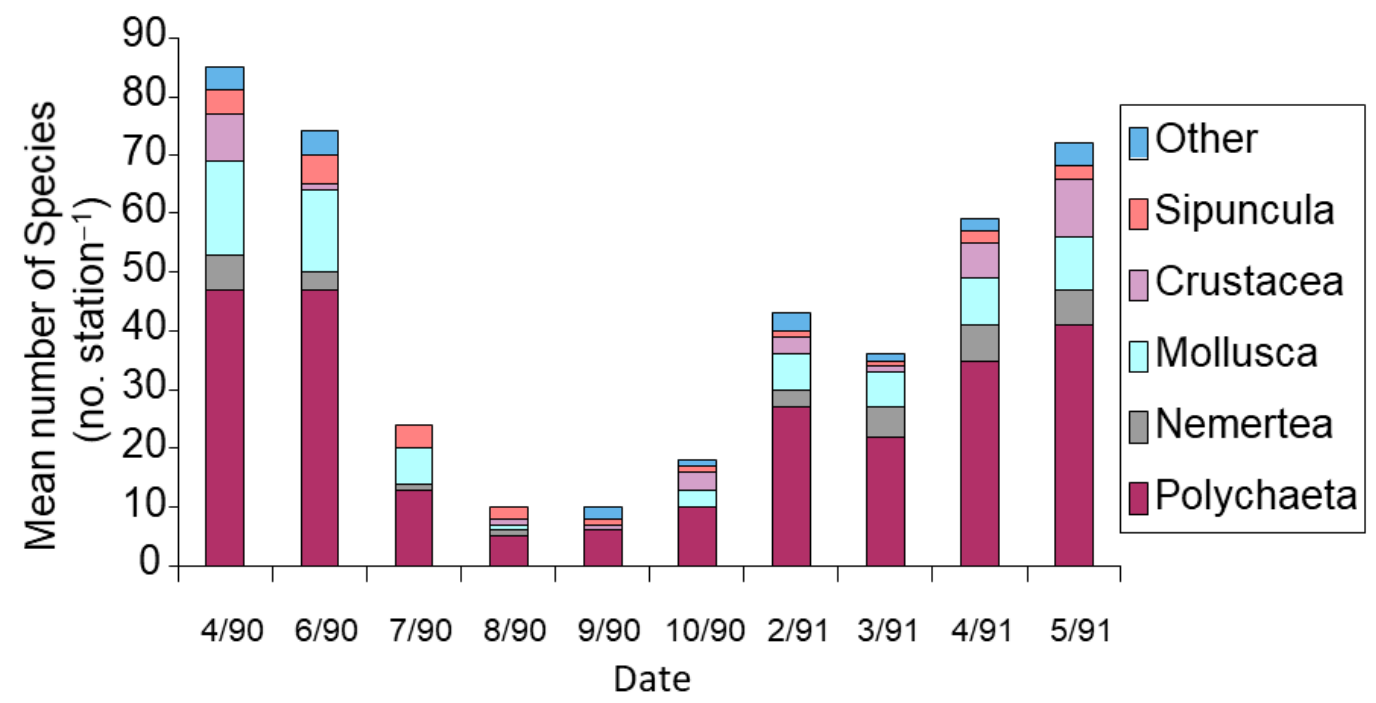

Figure 7. Mean number of species per station within taxonomic groups (total for $100.02-\mathrm{m}^{2}$ cores) at a persistently severe hypoxic station (C6 in Figure 1) for months indicated in 1990 and 1991 (modified from [15].

\subsection{Benthic Assemblages in 2003-2004}

A study of benthic infauna as forage for the abundant demersal fish, Atlantic croaker (Micropogonias undulatus) in the area of current hypoxia [29], provided an additional series of benthic infauna data for 
the period May 2003 through October 2004 [30]. Benthic samples were collected similar to [15] with three replicates per station. Sedimentology was similar and so was the water depth. The bottom-water hypoxia was more severe in summer 2003 than summer 2004, with 111 days of hypoxia from May to August 2003 but only 60 days for the same period in 2004 [30]. Benthic samples were not taken until mid-September of 2003 and continued through late October 2004. During the period of likely hypoxia, the bottom-water dissolved oxygen did not fall below $2 \mathrm{mg} \cdot \mathrm{L}^{-1}$ until June to August 2004 and was not as severely low as in similar dates in other years [30]. The abundance of benthic infauna fluctuated between 500 and $2000 \mathrm{~m}^{-2}$, and the species richness was between 5 to 10 species station ${ }^{-1}$ for the same period. The most abundant infauna were polychaetes with greater than $50 \%$ of the individuals through the year, and this percentage was higher than benthic communities in 1985-1986 and 1990-1991. Crustaceans that were common through most of the year were not common from August to October 2004, verifying their susceptibility to low oxygen. The four most abundant infauna were Paraprionospio pinnata, Nemertea sp. A, Armandia maculata, and Magelona sp., similar to other summer benthic communities. The spionid polychaete $P$. pinnata was the most abundant through the year and was dominant in September 2003 and July-October 2004 when the other three species declined. While the benthic infauna from the summer 2004 period were not indicatively of "severely stressed" benthic fauna, they were consistent with lower abundance and lower species richness in all preceding years.

\subsection{Shifts in Feeding Modes}

Another study comparison was the examination of feeding modes in 1978-1979 [17] and 1985-1986 [14], i.e., are the communities shifting from subsurface deposit feeders to surface deposit feeders as predicted in Figure 3? The feeding modes for polychaetes during summer hypoxia in 1978-1979 [17] versus 1985-1986 [14] were $52.6 \%$ versus $95.5 \%$ for surface deposit feeders, $37.2 \%$ versus $3.9 \%$ for subsurface deposit feeders, $3.9 \%$ versus none for omnivores, and $6.3 \%$ versus $0.6 \%$ for carnivores (Appendix C). The typical benthic infauna in recent severe summer hypoxia is composed of a few species of surface deposit feeders ( $95.5 \%$ of all polychaetes), a few other vermiform taxa, and minimal, if any, molluscs, crustaceans, or echinoderms. The abundance of primarily surface deposit feeders during summer 1990-1991 and 2004 occurred primarily in the upper $2 \mathrm{~cm}$ of the sediments, along with the opportunistic capitellid polychaete Mediomastus sp. [15,30].

\section{Discussion}

From data beginning in the early 1970s through 2004, we documented a sequence of benthic communities that coincides with our expectations of loss of species richness and abundance and a shift from multiple feeding modes to primarily surface deposit feeders as oxygen deficiency worsened (Figure 3). There are no studies of benthic macroinfauna from which to derive a history of the changes on the southeastern Louisiana continental shelf west of the Mississippi River delta prior to the early 1970s. Data from sediment cores indicate the beginning of bottom-water hypoxia in the 1950s and worsening during the 1970s [12]. Our studies focused on areas of similar depths, similar sedimentology, collected in similar manners, and all consistent with a $\geq 0.5-\mathrm{mm}$ sieve. The benthic data for the period 1972-1973 [19] focused primarily on molluscs and crustaceans and did not include polychaetes. Without complete systematic data, however, it was evident that these groups of organisms were highly diverse, represented many taxa, and had high species richness. Only one sample period, summer 1973, was "extremely" low in dissolved oxygen at a level of $1.4 \mathrm{mg} \cdot \mathrm{L}^{-1}$ and coincided with a 100+-year Mississippi River flood. (N.B. this value is not as low as current mid-summer dissolved oxygen values $[15,27]$.)

The data from spring and summer 1978 considered only polychaetes but their species richness was much higher than polychaetes identified in 1985-1986 [14]. They were distributed evenly between surface deposit feeders and subsurface deposit feeders in spring and summer 1978 along with a few carnivores and omnivores. An opposite trend was identified in the summer of 1985 in that the limited 
polychaetes were predominantly surface deposit feeders. The benthic community of polychaetes in summer 1978 was different between then and summer 1985.

In the intervening years from 1985 to the early 1990s, low dissolved oxygen conditions became more frequent and more severe in summer in the bottom waters of the study area. By the 1985-1986 benthic infaunal surveys, the number of individuals and species increased in spring over previous years, likely related to increased fixed carbon flux to the seabed (see sediment organic accumulation in sediment cores $[12,21]$ ). The lush seabed of fluxed organic carbon (Figure $8 \mathrm{~A}, \mathrm{~B}$ ) would be a favored habitat for larval recruitment, and many invertebrates do recruit. In June, July, and August, in response to persistently severe low oxygen or toxic hydrogen sulfide or both, the benthic infauna abundance was reduced substantially and the number of species in summer was reduced to a minimal number of surface deposit feeding polychaete species and other vermiforms, such as sipunculids [15].

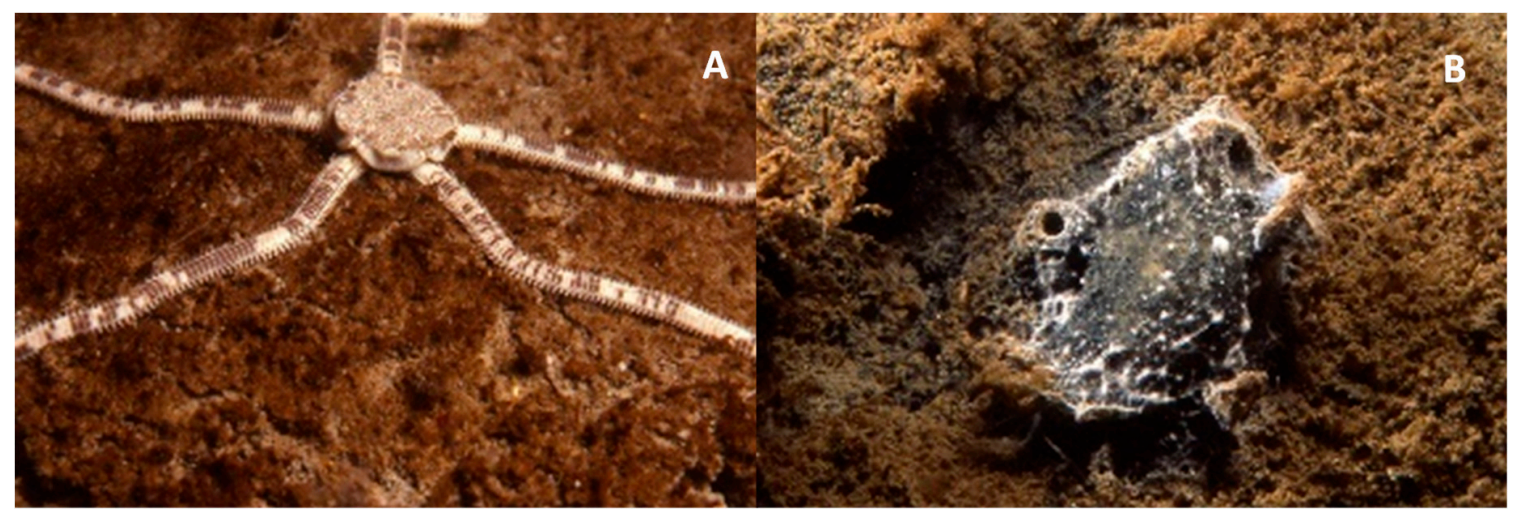

Figure 8. (A) An ophiuroid, Hemipholis elongata, at the sediment surface where it is not usually found on a seabed of rich organic detritus; (B) A sulfidic environment with organic detritus, anoxic sediments, sulfur-oxidizing bacteria, and the burrow of a live Diopatra cuprea (polychaete). Both photos taken in summer 1990; both organisms collected for later taxonomic determination (Photos curtesy of Franklin Viola for use by N.N. Rabalais).

The macroinfaunal abundance and species richness from studies on the southeastern Louisiana coast demonstrate the importance of nutrient-enhanced phytoplankton production in spring and oxygen depletion in summer for the formulation of benthic communities. Spring periods following flux of high river nutrient loads to the shelf are characterized by higher surface water chlorophyll $a$ biomass in spring followed by elevated levels of phaeopigments in summer [46], more species in spring in response to the high carbon flux, and retention of fluxed carbon in the sediments in summer (Figure 8A,B). Hypoxia in mid-summer is clearly reflected in an abrupt decline in abundance and diversity of benthic macroinfauna. Those that remain are primarily small opportunistic species specializing in surface deposit feeding within the upper few centimeters of the seabed. They do not burrow in the sediments deeper than the upper few centimeters, because the redox discontinuity layer is close to the sediment surface. When this occurs, there is likely an efflux of toxic $\mathrm{H}_{2} \mathrm{~S}$ and the nutrients $\mathrm{NH}_{4}{ }^{+}$and $\mathrm{PO}_{4}{ }^{-3}$ into the overlying hypoxic water column [11]. The effluxed nutrients can stimulate a negative indirect influence on hypoxia conditions by stimulating phytoplankton biomass accumulation from the surface waters, leading to additional carbon flux and further decline of bottom-water oxygen concentrations. The occurrence of $\mathrm{H}_{2} \mathrm{~S}$ and high carbon content of the sediments is supportive of resistant polychaete species that recruit rapidly in high numbers and/or are tolerant of low oxygen environments.

At least one abundant polychaete species, Paraprionospio pinnata, can delay settlement and remain in the water column until oxygen values return to a level above $2.0 \mathrm{mg} \cdot \mathrm{L}^{-1}$ [47]. They are fecund, recruit in large numbers, and the adults and larvae have enlarged branchiae and enzymatic adaptations for anaerobic metabolism $[48,49]$. Paraprionospio maintained abundances in the low $1000 \mathrm{~s} \mathrm{~m}^{-2}$ in 
summers 1985-1986 and 2001 [14,15]. Some macroinfauna, including the polychaetes Ampharete and Magelona and sipunculans, are capable of surviving extremely low dissolved oxygen levels and/or high hydrogen sulfide concentrations [50-52]. These are common summer polychaetes in seasonally severe low oxygen areas on the Louisiana continental shelf $[14,15]$.

What are often called "depauperate" benthic communities provide less biomass $[15,19]$ for feeding by demersal species, such as penaeid shrimp and the commonly occurring Atlantic croaker in the northern Gulf of Mexico in the areas where hypoxia occurs. These demersal species are also capable of moving inshore and offshore from the hypoxic zone where infaunal abundances will be higher (e.g., station C3 compared to C5) (Appendix B) [14]. How these stressed infaunal communities relate to altered trophic structure is unknown but worth investigating.

The shift over decades and among seasons from more diverse benthic organisms of both subsurface deposit feeders and surface deposit feeders with a mixture of carnivores and omnivores shifted to a much less diverse benthic community of fewer species that were primarily surface deposit feeders is apparent in the studies we reviewed. These shifts were consistent with our overall expectations of loss of polychaete species richness and shift in feeding modes as illustrated in Figure 3. A characteristic of the recent spring recruitment benthic community, however, is more diverse and abundant with polychaetes, consistent with increased organic matter flux to the seabed and adequate oxygen. Our data are far from complete but represent the best historical compilation possible and fit our proposed model for change over time.

The trajectory that we hypothesize from a healthy to a depauperate benthic system likely occurred over a long period, most likely beginning in the early 1950s. Returning to 1950's dissolved oxygen levels and benthic ecosystem will require a three-fold decrease, or more, in nitrogen loading to the northern Gulf of Mexico and time (see below). Based on the data compiled, we suggest that an initial shift occurred between the 1970s and the 1980s with another shift under severe hypoxia beginning then and into the 2000s. Duarte et al. [39] identified four examples of eutrophication followed by nutrient reductions and found no simple model of return to the initial ecosystem state because of regime shifts or shifting baselines or both. We would predict a regime shift and a new baseline for benthic communities beginning with a shift in nutrient levels and ratios at the base of the food web (phytoplankton) through a transition of unknown trajectories.

With little progress toward reducing nutrient loads, especially nitrogen, to the coastal waters from the Mississippi River watershed, it does not seem that a reversal of a stressed benthic community is likely in the near future. While some predict that return to "normal" conditions (i.e., limited hypoxia) would take multiple decades following reduction to nutrient load similar to the pre-1950s level [53]; others predict a shorter time period [54]. Besides seasonally severe hypoxia, multiple stressors, e.g., a warming climate, continued eruptions of noxious algal blooms including some harmful species, predictable increases in nutrient loads of the Mississippi River, disruption of the seabed, and proposed hydrologic changes in the discharge of the Mississippi River, will likely impact the coastal ocean in the northern Gulf of Mexico. Oil and gas exploration and production have occurred offshore Louisiana since the 1940s, but most environmental studies detect only localized effects related more to sediment granularity than potential toxicity $[19,23,55,56]$. The Deepwater Horizon oil spill affected deep-sea and continental slope sediments and benthic communities [57] where high levels of total hydrocarbons and polycyclic aromatic hydrocarbons were found (shallowest station was in $200 \mathrm{~m}$ ). Sediments from the continental shelf (13-83 m) collected in August 2011 were considered to be "relatively uncontaminated" with very low, often undetectable, levels of oil [58]. These oil spill related observations, however, do not allow for complacency in safe and non-polluting hydrocarbon extraction. The multiple current and future environmental pressures also do not overshadow the need for nutrient load mitigation to achieve progress in reducing areas of low oxygen and to promote recovering benthic communities.

Author Contributions: Conceptualization, N.N.R. and M.M.B.; writing-original draft preparation, N.N.R.; writing-review and editing, N.N.R. and M.M.B.; visualization, N.N.R. and M.M.B.; funding acquisition, N.N.R. All authors have read and agreed to the published version of the manuscript. 
Funding: This research depended on historic studies that received funding from several federal agencies and private industry. Benthic studies of Rabalais et al. and Baustian et al. were funded by the National Oceanic and Atmospheric Administration, Center for Sponsored Coastal Ocean Research.

Conflicts of Interest: The authors declare no conflict of interest. The funders of the research programs of N.N. Rabalais et al. and M.M. Baustian et al. had no role in the design of the study, in the collection, analyses, interpretation of data, the writing of the manuscript or in the decision to publish the results.

\section{Appendix A}

\section{Appendix A.1}

Stations of the Central Gulf Platform study and associated parameters for 1978; derived from data in [17]. Blue shading indicates hypoxia. Dissolved oxygen values were taken at 10-m intervals. Values of 2.40 were included with "hypoxia" because the deepest readings were at least $3 \mathrm{~m}$ above the seabed.

\begin{tabular}{|c|c|c|c|c|c|c|c|c|c|c|}
\hline Station & $\begin{array}{l}\text { Depth } \\
\text { (m) }\end{array}$ & $\begin{array}{c}\text { Sediment } \\
\text { Type }\end{array}$ & $\begin{array}{l}\text { Spr Surf } \\
\text { Salinity }\end{array}$ & $\begin{array}{l}\text { Spr Bott } \\
\text { Salinity }\end{array}$ & $\begin{array}{l}\text { Sum Surf } \\
\text { Salinity }\end{array}$ & $\begin{array}{l}\text { Sum Bott } \\
\text { Salinity }\end{array}$ & $\begin{array}{c}\text { Spr DO } \\
\text { Surf } \\
\left(\mathrm{mg} \cdot \mathrm{L}^{-1}\right)\end{array}$ & $\begin{array}{c}\text { Spr DO } \\
\text { Bott } \\
\left(\mathrm{mg} \cdot \mathrm{L}^{-1}\right)\end{array}$ & $\begin{array}{l}\text { Sum DO } \\
\text { Surf } \\
\left(\mathrm{mg} \cdot \mathrm{L}^{-1}\right)\end{array}$ & $\begin{array}{c}\text { Sum DO } \\
\text { Bott } \\
\left(\mathrm{mgL}^{-1}\right)\end{array}$ \\
\hline C21 & 14.0 & clayey silt & 22.8 & 32.8 & 25.8 & 33.0 & 14.00 & 3.00 & 6.60 & 2.40 \\
\hline $\mathrm{C} 22$ & 21.0 & sandy silt & 27.8 & 36.0 & 32.1 & 35.0 & 8.00 & 1.60 & 6.40 & 6.00 \\
\hline $\mathrm{C} 23$ & 37.0 & silt & 36.0 & 36.1 & 30.4 & 34.5 & 6.80 & 7.60 & 4.50 & 4.60 \\
\hline C24 & 17.0 & silt & 31.1 & 35.5 & 32.2 & 33.2 & 7.20 & 1.30 & 6.30 & 6.20 \\
\hline P1 & 16.0 & sandy silt & 13.4 & 35.9 & 26.9 & 34.3 & 10.00 & 3.10 & 9.60 & 1.60 \\
\hline P2 & 14.0 & silty sand & 23.4 & 31.8 & 21.9 & 32.8 & 13.00 & 6.20 & 9.60 & 2.40 \\
\hline P3 & 29.0 & sand & 34.8 & 36.2 & 30.1 & 36.6 & 6.40 & 4.40 & 6.20 & 4.20 \\
\hline
\end{tabular}

Appendix A.2

The abundance of polychaetes and number of species from the Central Gulf Platform Study in 1978 [17]. Blue shading indicates hypoxia (Appendix A.1).

\begin{tabular}{|c|c|c|c|c|}
\hline Station & $\begin{array}{c}\text { Spring Polychaete } \\
\text { Abundance } \\
\text { (Indiv. Station }^{-1} \text { ) }\end{array}$ & $\begin{array}{c}\text { Spring Species } \\
\text { Richness } \\
\text { (NumberStation }^{-1} \text { ) }\end{array}$ & $\begin{array}{c}\text { Summer Polychaete } \\
\text { Abundance } \\
\text { (Indiv. Station }^{-1} \text { ) }\end{array}$ & $\begin{array}{c}\text { Summer Species } \\
\text { Richness } \\
\left(\text { Number Station }{ }^{-1}\right)\end{array}$ \\
\hline $\mathrm{C} 21$ & 2767.0 & 33.0 & 32.0 & 4.0 \\
\hline $\mathrm{C} 22$ & 1376.0 & 42.0 & 73.0 & 18.0 \\
\hline $\mathrm{C} 23$ & 397.0 & 32.0 & 240.0 & 25.0 \\
\hline $\mathrm{C} 24$ & 1377.0 & 18.0 & 108.0 & 16.0 \\
\hline $\mathrm{P} 1$ & 1601.0 & 31.9 & 172.5 & 14.1 \\
\hline P2 & 2662.6 & 58.1 & 413.8 & 11.3 \\
\hline P3 & 1050.8 & 53.4 & 392.8 & 39.0 \\
\hline
\end{tabular}

\section{Appendix B}

Polychaete data from stations C3, C4, and C5 (Figure 1) in 1985-1986 [14]. Sediments were mostly sandy mud for C4 and C5, with more sand in C3. Station C3 in $10.6 \mathrm{~m}$ is more likely to have a mixed water column, i.e., less hypoxia, than stations in 13.1 and $16 \mathrm{~m}$. Data from stations C4 and C5 were most comparable to the depths, sediment types, and areas studied in 1978 [17] and were used for comparisons to those data. These data were used to develop Figure 5. Cells highlighted in blue indicate samples for which bottom-water dissolved oxygen values were $\leq 2 \mathrm{mg} \cdot \mathrm{L}^{-1}$. 


\begin{tabular}{|c|c|c|c|c|c|c|c|c|}
\hline Station & $\begin{array}{l}\text { Depth } \\
\text { (m) }\end{array}$ & Date & $\begin{array}{l}\text { Surface } \\
\text { Salinity }\end{array}$ & $\begin{array}{l}\text { Bottom } \\
\text { Salinity }\end{array}$ & $\begin{array}{l}\text { Surface } \\
\text { Dissolved } \\
\text { Oxygen } \\
\left(\mathrm{mg} \cdot \mathrm{L}^{-1}\right)\end{array}$ & $\begin{array}{l}\text { Bottom } \\
\text { Dissolved } \\
\text { Oxygen } \\
\left(\mathrm{mg} \cdot \mathrm{L}^{-1}\right)\end{array}$ & $\begin{array}{l}\text { Polychaete } \\
\text { Abundance } \\
\left(\text { no. } \mathrm{m}^{-2} \text { ) }\right.\end{array}$ & $\begin{array}{c}\text { Number of } \\
\text { Polychaete } \\
\text { Species Per } \\
\text { Station }\end{array}$ \\
\hline $\mathrm{C} 3$ & 10.6 & $6 / 26 / 85$ & 20.3 & 30.6 & 8.80 & 3.00 & 14,578 & 10 \\
\hline $\mathrm{C} 4$ & 13.1 & $6 / 26 / 85$ & 19.6 & 33.4 & 9.50 & 0.20 & 8434 & 7 \\
\hline C5 & 16.3 & $6 / 27 / 85$ & 22.0 & 34.9 & 8.70 & 0.17 & 4458 & 6 \\
\hline $\mathrm{C} 3$ & 10.6 & $7 / 9 / 85$ & 25.3 & 29.9 & 8.70 & 2.10 & 15,060 & 5 \\
\hline $\mathrm{C} 4$ & 13.1 & $7 / 9 / 85$ & 25.2 & 34.1 & 8.10 & 0.17 & 5181 & 5 \\
\hline C5 & 16.3 & $7 / 10 / 85$ & 25.8 & 34.9 & 7.40 & 0.27 & 6124 & 7 \\
\hline $\mathrm{C} 3$ & 10.6 & $7 / 15 / 85$ & 25.1 & 34.7 & 6.60 & 0.33 & 5060 & 7 \\
\hline $\mathrm{C} 4$ & 13.1 & $8 / 6 / 85$ & 27.3 & 34.9 & 6.80 & 0.18 & 2169 & 5 \\
\hline C5 & 16.3 & $8 / 6 / 85$ & 25.8 & 35.4 & 6.10 & 0.13 & 904 & 2 \\
\hline $\mathrm{C} 3$ & 10.6 & $9 / 6 / 85$ & 28.8 & 30.6 & 5.70 & 5.00 & 14,699 & 12 \\
\hline $\mathrm{C} 4$ & 13.1 & $9 / 6 / 85$ & 30.4 & 30.9 & 7.40 & 6.20 & 6827 & 9 \\
\hline $\mathrm{C} 5$ & 16.3 & $9 / 6 / 85$ & 31.2 & 31.2 & 6.30 & 6.20 & 1506 & 8 \\
\hline $\mathrm{C} 3$ & 10.6 & $10 / 10 / 85$ & 29.8 & 29.8 & 6.50 & 6.50 & 8434 & 8 \\
\hline $\mathrm{C} 4$ & 13.1 & $10 / 10 / 85$ & 30.5 & 30.5 & 6.40 & 6.40 & 5422 & 10 \\
\hline C5 & 16.3 & $10 / 10 / 85$ & 30.8 & 30.9 & 6.40 & 6.40 & 3414 & 8 \\
\hline $\mathrm{C} 3$ & 10.6 & $12 / 9 / 85$ & 25.1 & 25.6 & 8.00 & 8.00 & 5271 & 11 \\
\hline $\mathrm{C} 4$ & 13.1 & $12 / 9 / 85$ & 25.7 & 27.0 & 7.80 & 6.70 & 4217 & 10 \\
\hline C5 & 16.3 & $12 / 9 / 85$ & 26.8 & 28.5 & 7.60 & 6.00 & 2289 & 6 \\
\hline C3 & 10.6 & $1 / 30 / 86$ & 29.5 & 29.6 & 9.50 & 9.40 & 1807 & 2 \\
\hline C4 & 13.1 & $1 / 30 / 86$ & 29.9 & 30.1 & 8.40 & 8.00 & 703 & 2 \\
\hline C5 & 16.3 & $1 / 30 / 86$ & 30.3 & 30.8 & 7.20 & 6.80 & 1807 & 2 \\
\hline $\mathrm{C} 3$ & 10.6 & $3 / 3 / 86$ & 29.3 & 31.6 & 7.60 & 4.60 & 5020 & 9 \\
\hline $\mathrm{C} 4$ & 13.1 & $3 / 3 / 86$ & 29.1 & 31.6 & 7.60 & 5.40 & 3494 & 8 \\
\hline C5 & 16.3 & $3 / 3 / 86$ & 29.6 & 32.1 & 7.60 & 4.60 & 3494 & 11 \\
\hline $\mathrm{C} 3$ & 10.6 & $4 / 17 / 86$ & 28.7 & 31.3 & 9.40 & 1.90 & 67,711 & 19 \\
\hline $\mathrm{C} 4$ & 13.1 & $4 / 17 / 86$ & 29.3 & 30.8 & 8.80 & 3.50 & 49,157 & 15 \\
\hline C5 & 16.3 & $4 / 17 / 86$ & 29.5 & 31.1 & 9.20 & 6.30 & 20,120 & 15 \\
\hline $\mathrm{C} 3$ & 10.6 & $5 / 28 / 86$ & 27.7 & 32.8 & 7.20 & 3.50 & 45,542 & 19 \\
\hline $\mathrm{C} 4$ & 13.1 & $5 / 28 / 86$ & 28.3 & 33.3 & 6.70 & 2.00 & 79,157 & 13 \\
\hline C5 & 16.3 & $5 / 28 / 86$ & 29.1 & 33.5 & 7.00 & 2.50 & 64,217 & 15 \\
\hline $\mathrm{C} 3$ & 10.6 & $6 / 27 / 86$ & 17.2 & 29.0 & 6.90 & 5.30 & 13,494 & 5 \\
\hline C4 & 13.1 & $6 / 27 / 86$ & 17.8 & 30.5 & 7.50 & 3.60 & 64,940 & 12 \\
\hline C5 & 16.3 & $6 / 27 / 86$ & 16.8 & 34.0 & 9.20 & 0.46 & 16,265 & 7 \\
\hline C3 & 10.6 & $7 / 22 / 86$ & 26.6 & 35.5 & 6.20 & 0.22 & 3735 & 5 \\
\hline $\mathrm{C} 4$ & 13.1 & $7 / 22 / 86$ & 27.4 & 35.7 & 6.00 & 0.19 & 16,747 & 4 \\
\hline C5 & 16.3 & $7 / 22 / 86$ & 26.9 & 35.6 & 6.10 & 0.21 & 4578 & 3 \\
\hline $\mathrm{C} 3$ & 10.6 & $8 / 19 / 86$ & 30.6 & 34.50 & 6.00 & 0.20 & 6024 & 6 \\
\hline C4 & 13.1 & $8 / 19 / 86$ & 31.0 & 34.50 & 6.20 & 0.30 & 29,639 & 4 \\
\hline C5 & 16.3 & $8 / 19 / 86$ & 31.3 & 34.40 & 6.40 & 0.32 & 22,169 & 7 \\
\hline
\end{tabular}

\section{Appendix C}

Dominant polychaetes in spring and summer of 1978, in declining abundance [17] and in spring and summer for 1985-1986 for [14] and their feeding modes. Declining abundance for [17] is the relative proportion of all species that constitute $>75 \%$ for all collections. Abundance in the 1985-1986 samples [14] is the number of all genera collected at stations C4 and C5. Feeding modes are SD-surface deposit feeder, $\mathrm{SbD}$-subsurface deposit feeder, $\mathrm{C}$-carnivore, O-omnivore; suspension feeders were not found. Feeding mode information is from $[18,45]$. 


\begin{tabular}{|c|c|c|c|c|c|c|c|c|c|c|c|}
\hline \multicolumn{3}{|c|}{$\begin{array}{l}\text { Spring Dominant Polychaetes } \\
1978 \text { [17] }\end{array}$} & \multicolumn{3}{|c|}{$\begin{array}{l}\text { Spring 1985-1986 Dominant } \\
\text { Polychaetes [14] }\end{array}$} & \multicolumn{3}{|c|}{$\begin{array}{l}\text { Summer Dominant Polychaetes } \\
\qquad 1978 \text { [17] }\end{array}$} & \multicolumn{3}{|c|}{$\begin{array}{c}\text { Summer 1895-1986 Dominant } \\
\text { Polychaetes [14] }\end{array}$} \\
\hline Genus & $\begin{array}{l}>75 \% \text { Cum } \\
\text { Number }\end{array}$ & $\begin{array}{l}\text { Feeding } \\
\text { Mode }\end{array}$ & Genus & $\begin{array}{l}\text { Stations } \\
\text { C4 and C5 }\end{array}$ & $\begin{array}{l}\text { Feeding } \\
\text { Mode }\end{array}$ & Genus & $\begin{array}{l}>75 \% \text { Cum } \\
\text { Number }\end{array}$ & $\begin{array}{l}\text { Feeding } \\
\text { Mode }\end{array}$ & Genus & $\begin{array}{l}\text { Stations } \\
\mathrm{C} 4 \text { and } \mathrm{C} 5\end{array}$ & $\begin{array}{l}\text { Feeding } \\
\text { Mode }\end{array}$ \\
\hline Paraprionospio & 36.6 & $\mathrm{SD}$ & Paraprionospio & 498 & SD & Paraprionospio & 25.1 & SD & Magelona & 168 & SD \\
\hline Mediomastus & 51.1 & $\mathrm{SbD}$ & Magelona & 375 & $\mathrm{SD}$ & Sigambra & 27.6 & $\mathrm{C}$ & Ancistrosyllis & 4 & $\mathrm{C}$ \\
\hline Tharyx & 52.8 & $\mathrm{SbD}$ & Mediomastus & 43 & $\mathrm{SbD}$ & Magelona & 52.6 & $\mathrm{SD}$ & Sigambra & 3 & $\mathrm{C}$ \\
\hline Aricidea & 54.0 & $\mathrm{SbD}$ & Sabellides & 137 & $\mathrm{SD}$ & Notomastus & 55.1 & $\mathrm{SbD}$ & Ampharete & 1 & SD \\
\hline Notomastus & 54.9 & $\mathrm{SbD}$ & Sigambra & 11 & $\mathrm{C}$ & Lumbrineris & 59.0 & $\mathrm{O}$ & Melinna & 1 & $\mathrm{SD}$ \\
\hline Cossura & 55.7 & $\mathrm{SbD}$ & Gyptis & 4 & $\mathrm{C}$ & Diopatra & 60.7 & C & Cossura & 1 & $\mathrm{SbD}$ \\
\hline Prionospio & 56.8 & $\mathrm{SD}$ & Polynoidae & 1 & $\mathrm{O}$ & Cossura & 62.3 & $\mathrm{SbD}$ & & & \\
\hline Diopatra & 57.6 & $\mathrm{C}$ & Prionospio & 6 & SD & Nereis & 68.2 & C & & & \\
\hline Nereis & 59.3 & C & Eumida & 6 & $\mathrm{O}$ & Nephtys & 73.5 & $\mathrm{O}$ & & & \\
\hline Sthenelais & 60.8 & $\mathrm{C}$ & Cossura & 2 & $\mathrm{SbD}$ & & & & & & \\
\hline Phyllodoce & 61.4 & $\mathrm{C}$ & Ancistrosyllis & 1 & C & & & & & & \\
\hline Lumbrineris & 62.0 & $\mathrm{O}$ & Aricidea & 3 & SD & & & & & & \\
\hline Magelona & 63.2 & SD & Glycinde & 2 & $\mathrm{C}$ & & & & & & \\
\hline Prionospio & 71.7 & SD & Chaetozone & 28 & SD & & & & & & \\
\hline Glycera & 73.1 & $\mathrm{C}$ & Diopatra & 3 & $\mathrm{C}$ & & & & & & \\
\hline Chaetozone & 73.5 & $\mathrm{SD}$ & Polydora & 18 & SD & & & & & & \\
\hline \multirow[t]{4}{*}{ Armandia } & 74.0 & $\mathrm{SbD}$ & Ampharete & 11 & SD & & & & & & \\
\hline & & & Nereis & 1 & $\mathrm{C}$ & & & & & & \\
\hline & & & Tharyx & 1 & $\mathrm{SD}$ & & & & & & \\
\hline & & & Pseudolpolydora & 1 & $\mathrm{SbD}$ & & & & & & \\
\hline
\end{tabular}




\section{References}

1. Rabalais, N.N.; Turner, R.E. Management Case Study: Mississippi River. In Treatise on Estuarine and Coastal Science; Wolanski, E., McLusky, D.S., Eds.; Academic Press: Waltham, MA, USA, 2011; Volume 11, pp. $77-101$.

2. Rabalais, N.N.; Díaz, R.J.; Levin, L.A.; Turner, R.E.; Gilbert, D.; Zhang, J. Dynamics and distribution of natural and human-caused coastal hypoxia. Biogeosciences 2010, 7, 585-619. [CrossRef]

3. Mississippi River Nutrient/Gulf of Mexico Hypoxia Task Force. Action Plan for Reducing, Mitigating, and Controlling Hypoxia in the Northern Gulf of Mexico; Office of Wetlands, Oceans, and Watersheds, U.S. Environmental Protection Agency: Washington, DC, USA, 2001.

4. Mississippi River/Gulf of Mexico Watershed Nutrient Task Force. Hypoxia Task Force Report to Congress; Environmental Protection Agency: Washington, DC, USA, 2015. [CrossRef]

5. PaveIa, J.S.; Ross, J.L.; Chittenden, M.E., Jr. Sharp reductions in abundance of fishes and benthic macroinvertebrates in the Gulf of Mexico off Texas associated with hypoxia. Northeast Gulf Sci. 1983, 6, 167-173.

6. Renaud, M. Hypoxia in Louisiana coastal waters during 1983: Implications for fisheries. Fish. Bull. 1986, 84, $19-26$.

7. Craig, J.K.; Crowder, L.B. Hypoxia-induced habitat shifts and energetic consequences in Atlantic croaker and brown shrimp on the Gulf of Mexico shelf. Mar. Ecol. Prog. Ser. 2005, 294, 79-94. [CrossRef]

8. Smith, M.D.; Asche, F.; Bennear, L.S.; Oglend, A. Spatial-dynamics of hypoxia and fisheries: The case of Gulf of Mexico brown shrimp. Mar. Res. Econ. 2014, 29, 111-131. [CrossRef]

9. Smith, M.D.; Oglend, A.; Kirkpatrick, A.J.; Asche, F.; Bennear, L.S.; Craig, J.K.; Nance, J.M. Seafood prices reveal impacts of a major ecological disturbance. Proc. Natl. Acad. Sci. USA 2017, 201617948. [CrossRef]

10. Purcell, K.M.; Craig, J.K.; Nance, J.M.; Smith, M.D.; Bennear, L.S. Fleet behavior is responsive to a large-scale environmental disturbance: Hypoxia effects on the spatial dynamics of the northern Gulf of Mexico shrimp fishery. PLoS ONE 2017, 12, e0183032. [CrossRef]

11. Rabalais, N.N. Ocean Deoxygenation: Everyone's Problem: Causes, Impacts, Consequences and Solutions; IUCN: Gland, Switzerland, 2019; pp. 399-419.

12. Rabalais, N.N.; Turner, R.E.; Sen Gupta, B.K.; Platon, E.; Parsons, M.L. Sediments tell the history of eutrophication and hypoxia in the northern Gulf of Mexico. Ecol. Appl. 2007, 17, S129-S143. [CrossRef]

13. Rabalais, N.N.; Smith, L.M.; Turner, R.E. The Deepwater Horizon oil spill and Gulf of Mexico shelf hypoxia. Cont. Shelf Res. 2018, 152, 98-107. [CrossRef]

14. Rabalais, N.N. (Louisiana State University, Baton Rouge, LA, USA). Benthic studies on the northern Gulf of Mexico in a seasonally severe zone of oxygen depletion in 1985-1986. Personal communication, unpublished data, 2019.

15. Rabalais, N.N.; Smith, L.E.; Harper, D.E., Jr.; Justić, D. Effects of seasonal hypoxia on continental shelf benthos. In Coastal Hypoxia: Consequences for Living Resources and Ecosystems; Rabalais, N.N., Turner, R.E., Eds.; American Geophysical Union: Washington, DC, USA, 2001; pp. 211-240.

16. Turner, R.E.; Rabalais, N.N.; Swenson, E.M.; Kasprzak, M.; Romaire, T. Summer hypoxia in the northern Gulf of Mexico and its prediction from 1978 to 1995. Mar. Envtl. Res. 2005, 59, 65-77. [CrossRef]

17. Fitzhugh, J.K. Factors Determining the Distribution and Abundance of Polychaetous Annelids on the Central Northern Gulf of Mexico Continental Shelf. Master's Thesis, Texas A\&M University, College Station, TX, USA, August 1983.

18. Shivarudrappa, S.K.; Briggs, K.B. Macrobenthos community succession in the northern Gulf of Mexico hypoxic regions: Testing the Pearson-Rosenberg model. J. Mar. Res. 2017, 75, 18-46. [CrossRef]

19. Farrell, D.H. Benthic Ecology of Timbalier Bay, Louisiana, and Adjacent Offshore Areas in Relation to Oil Production. Ph.D. Dissertation, Florida State University, Tallahassee, FL, USA, December 1974.

20. Rabalais, N.N.; Turner, R.E.; Scavia, D. Beyond science into policy: Gulf of Mexico hypoxia and the Mississippi River. BioScience 2002, 52, 129-142. [CrossRef]

21. Rabalais, N.N.; Cai, W.-J.; Carstensen, J.; Conley, D.J.; Fry, F.; Quiñones-Rivera, Z.; Rosenberg, R.; Slomp, C.P.; Turner, R.E.; Voss, M.; et al. Eutrophication-driven deoxygenation in the coastal ocean. Oceanography 2014, 70, 123-133. 
22. Oetking, P.; Back, R.; Watson, R.; Merks, C. Hydrography on the Nearshore Continental Shelf of South Central Louisiana: Final Report of Offshore Ecology Investigation for Gulf Universities Research Consortium, Project No. 03-3720; Southwest Research Institute: Galveston, TX, USA; Corpus Christi, TX, USA, 1974.

23. Ward, C.H.; Bender, M.E.; Reish, D.J. The Offshore Ecology Investigation. Effects of oil drilling and production in a coastal environment. Rice Univ. Stud. 1979, 65, 1-589.

24. Turner, R.E.; Swenson, E.M.; Kasprzak, M.; Romaire, T. Vol. 2. Water Chemistry. LOOP Marine and Estuarine Monitoring Program, 1978-1995; Sasser, C.E., Visser, J.M., Eds.; Res. Rep. No. 316, LTRC Project No. 97-31MP, State Proj. No. 736-99-0449; Conducted for the Louisiana Transportation Research Center: Baton Rouge, LA, USA, 1998.

25. Ragan, J.G.; Harris, A.H.; Green, J.H. Temperature, Salinity and Oxygen Measurements of Surface and Bottom Waters on the Continental Shelf off Louisiana during Portions of 1975 and 1976; Professional Paper Series 3; Biology, Nicholls State University: Thibodaux, LA, USA, 1978; pp. 1-29.

26. Turner, R.E.; Allen, R.L. 1982. Bottom water oxygen concentration in the Mississippi River Delta bight. Contr. Mar Sci. 1982, 25, 161-172.

27. Rabalais, N.N.; Turner, R.E. Gulf of Mexico hypoxia: Past, present, and future. Limnol. Oceanogr. Bull. 2019, 28, 1-8. [CrossRef]

28. Boesch, D.F.; Rabalais, N.N. Effects of hypoxia on continental shelf benthos: Comparisons between the New York Bight and the northern Gulf of Mexico. In Modern and Ancient Continental Shelf Anoxia Geological Society Spec. Publ.; Tyson, R.V., Pearson, T.H., Eds.; The Geological Society: London, UK, 1991; Volume 58, pp. 27-34.

29. Baustian, M.M.; Craig, J.K.; Rabalais, N.N. Effects of summer 2003 hypoxia on macrobenthos and Atlantic croaker foraging selectivity in the northern Gulf of Mexico. J. Exp. Mar. Biol. Ecol. 2009, 381, S31-S37. [CrossRef]

30. Baustian, M.M.; Rabalais, N.N. Seasonal composition of benthic macroinfauna exposed to hypoxia in the northern Gulf of Mexico. Estuar. Coasts 2009, 32, 975-983. [CrossRef]

31. Flowers, C.W.; Miller, W.T.; Gann, J.D. Water Chemistry. In Environmental Assessment of a Louisiana Offshore Oil Port and Apertinent Storage and Pipeline Facilities-Technical Appendices, Vol. II; Gosselink, J.G., Miller, R.H., Hood, M., Bahr, L.M., Eds.; Final Report to the Louisiana Offshore Oil Port, Inc.: New Orleans, LA, USA, 1975.

32. Gaston, G.R.; Vittor, B.A.; Barrett, B.; Wolf, P.S. Benthic Communities of Louisiana Coastal Waters; Technical Bulletin No. 45; Report to the Louisiana Department of Wildlife and Fisheries: Baton Rouge, LA, USA, 1998.

33. Pearson, T.H.; Rosenberg, R. Macrobenthic succession in relation to organic enrichment and pollution in the marine environment. Oceanogr. Mar. Biol. Ann. Rev. 1978, 16, 229-231.

34. Turner, R.E.; Rabalais, N.N.; Justić, D. Summer bottom-water temperature trends northern Gulf of Mexico continental shelf, 1985 to 2015. PLoS ONE 2017, 12, e0184350. [CrossRef]

35. Hart, R.A.; Nance, J.M. Three decades of U.S. Gulf of Mexico white shrimp, Litopenaeus setiferus, commercial catch statistics. Mar. Fish. Rev. 2012, 75, 43-47. [CrossRef]

36. Wells, R.J.D.; Cowan, J.H., Jr.; Patterson, W.F., III. Habitat use and the effect of shrimp trawling on fish and invertebrate communities over the northern Gulf of Mexico continental shelf. ICES J. Mar. Sci. 2008, 65, 1610-1619. [CrossRef]

37. Sheridan, P.; Doerr, J. Short-term effects of the cessation of shrimp trawling on Texas benthic habitats. Am. Fish. Soc. Symp. 2005, 41, 571-578.

38. Smith, J.E.; Bentley, S.J.; Snedden, G.A.; White, C. What role do hurricanes play in sedimentary delivery to subsiding river deltas? Sci. Rep. 2015, 5, 17582. [CrossRef]

39. Duarte, C.M.; Conley, D.J.; Carstensen, J.; Sánchez-Camacho, M. Return to Neverland: Shifting baselines affect eutrophication restoration targets. Estuar. Coasts 2009, 32, 29-36. [CrossRef]

40. Harper, D.E., Jr.; McKinney, L.D.; Salzer, R.R.; Case, R.J. The occurrence of hypoxic bottom water off the upper Texas coast and its effects on the benthic biota. Contr. Mar. Sci. 1981, 24, 53-79.

41. Gaston, G.R. Effects of hypoxia on macrobenthos of the inner shelf off Cameron, Louisiana. Estuar. Coast. Shelf Sci. 1985, 20, 603-613. [CrossRef]

42. Gaston, G.R.; Rutledge, P.A.; Walther, M.L. The effects of hypoxia and brine on recolonization by macrobenthos off Cameron, Louisiana (USA). Contr. Mar. Sci. 1985, 28, $29-93$. 
43. Bedinger, C.A., Jr.; Childers, R.E.; Cooper, J.; Kimball, K.T.; Kwok, A. Background, Program Organization and Study Plan. Ecological Investigations of Petroleum Production Platforms in the Central Gulf of Mexico. Vol. 1 (Sec. 1); Report to Bureau of Land Management Contract No. AA551-CT-8-17; Southwest Research Institute: San Antonio, TX, USA, 1981.

44. Shivarudrappa, S. Macrobenthic Communities in the Northern Gulf of Mexico Hypoxic Zone: Testing the Pearson-Rosenberg Model. Ph.D. Dissertation, University of Southern Mississippi, Hattiesburg, MS, USA, December 2015.

45. Rabalais, N.N.; Wiseman, W.J., Jr.; Turner, R.E. Comparison of continuous records of near-bottom dissolved oxygen from the hypoxia zone along the Louisiana coast. Estuaries 1994, 17, 850-861. [CrossRef]

46. Rabalais, N.N.; Turner, R.E.; Wiseman, W.J., Jr.; Dortch, Q. Consequences of the 1993 Mississippi River flood in the Gulf of Mexico. Reg. Rivers: Res. Mngt. 1998, 14, 161-177. [CrossRef]

47. Powers, S.P.; Harper, D.E., Jr.; Rabalais, N.N. Effect of hypoxia/anoxia on the supply and settlement of benthic invertebrate larvae. In Coastal Hypoxia: Consequences for Living Resources and Ecosystems; Rabalais, N.N., Turner, R.E., Eds.; American Geophysical Union: Washington, DC, USA, 2001; pp. 185-210.

48. Quiroga, E.; Quiñones, R.A.; González, R.R.; Gallardo, V.A.; Gerdhard, J. Aerobic and anaerobic metabolism of Paraprionospio pinnata (Polychaeta: Spionidae) in central Chile. J. Mar. Biol. Assoc. UK 2007, 87, 459-463. [CrossRef]

49. Levin, L.A.; Ekau, W.; Gooday, A.; Jorrisen, F.; Middelburg, J.; Naqvi, W.; Neira, C.; Rabalais, N.N.; Zhang, J. Effects of natural and human-induced hypoxia on coastal benthos. Biogeoscience 2009, 6, 2063-2098. [CrossRef]

50. Josefson, A.B.; Widbom, B. Differential response of benthic macrofauna and meiofauna to hypoxia in the Gullmar Fjord basin. Mar. Biol. 1988, 100, 31-40. [CrossRef]

51. Yokoyama, H. Occurrence of Paraprionospio sp. (form A) larvae (Polychaeta: Spionidae) in hypoxic waters of an enclosed bay. Estuar. Coast. Shelf Sci. 1995, 40, 9-19. [CrossRef]

52. Lamont, P.A.; Gage, J.D. Morphological responses of macrobenthic polychaetes to low oxygen on the Oman continental slope, NW Arabian Sea. Deep-Sea Res. 2000, 47, 9-24. [CrossRef]

53. Van Meter, K.J.; Van Cappellen, P.; Basu, N.B. Legacy nitrogen may prevent achievement of water quality goals in the Gulf of Mexico. Science 2018, 360, 427-430. [CrossRef]

54. Ballard, T.C.; McIsaac, G.F.; Michalak, A.M.; Rabalais, N.N.; Turner, R.E. Comment on “Legacy nitrogen may prevent achievement of water quality goals in the Gulf of Mexico.". Science 2019, 365, eaau8401. [CrossRef]

55. Rabalais, N.N.; McKee, B.A.; Reed, D.J.; Means, J.C. Fate and effects of produced water discharges in coastal Louisiana, Gulf of Mexico, USA. In Produced Water; Ray, J.P., Engelhardt, F.R., Eds.; Plenum Press: New York, NY, USA, 1992; pp. 355-369.

56. Montagna, P.A.; Harper, D.E., Jr. Benthic infaunal long-term response to offshore production platforms in the Gulf of Mexico. Can. J. Fish. Aquat. Sci. 1996, 53, 2567-2588. [CrossRef]

57. Montagna, P.A.; Baguley, J.G.; Cooksey, C.; Hartwell, I.; Hyde, L.J.; Hyland, J.L.; Kalke, R.D.; Kracker, L.M.; Reuscher, M.; Rhodes, A.C.E. Deep-sea benthic footprint of the Deepwater Horizon blowout. PLoS ONE 2013, 8, e70540. [CrossRef]

58. Ecological Condition of Coastal Ocean Waters of the Western Gulf of Mexico: 2011. Available online: http://aquaticcommons.org/14670/1/NOS\%20NCCOS\%20171.pdf (accessed on 1 January 2020).

(C) 2020 by the authors. Licensee MDPI, Basel, Switzerland. This article is an open access article distributed under the terms and conditions of the Creative Commons Attribution (CC BY) license (http://creativecommons.org/licenses/by/4.0/). 